Jariwalla, A. G., Adams, P. H. \& Hore, B. D. (1979) Alcohol and acute general medical admissions to hospital. Health Medical Journal, ii, 95-97.

JARMAN, C. M. B. \& KelLET, J. M. (1979) Alcoholism in the General Hospital. British Medical Journal, ii, 469-472.

MOORE, R. A. (1971) The prevalence of alcoholism in a community general hospital. American Journal of Psychiatry, 128, 638-639.

Universiti Kebangsaan Malaysia

SAROJA K. INDRAN

50300 Jalan Raja Muda Abdul Aziz

Kuala Lumpur

Malaysia

\section{A man who does not use his arms}

Case report. $\mathrm{Mr} \mathrm{X}$ initially presented asking for amputation of both arms. He was in his 30s, small, and barefoot but otherwise fully clothed, although his trousers were incompletely fastened. His arms were held underneath his shirt, behind his back, his hands resting on his buttocks inside his trousers, while the sleeves of his jacket hung loosely at his side. He wore his wristwatch on his ankle and during conversation gesticulated with his feet. He used his feet to open doors and reported using them to eat, type, and drive. He described his problem as: "I can't - or rather I won't - use my arms". He was seeking psychiatric support for surgical amputation. He had thought of waiting beside a railway line with his arms over the tracks but feared that this method would also kill him. He subsequently presented on two occasions with a belt fastened around his left arm as a tourniquet, which he removed on request. He refused psychiatric assessment until he needed medical support to train on a disabled person's scheme.

He described feeling that his arms were alien to him from the age of nine, when he had seen television documentaries about thalidomide victims. When alone he would secretly use his feet to carry out actions such as opening cupboards. From his early teens there were short periods when he would lose power in both arms. This would happen suddenly, preceded by anxiety, and lasted for only a few minutes. In his 20 s he began to avoid use of his arms in public, and to make contact with disabled people. In his early 30 s he was dismissed from his job in a building society when, while visiting the home of a client, he exposed himself after unfastening his trousers to emphasise the problems of his disability. At that time he was referred to a psychotherapy group by a psychiatrist, but refused to attend.

He blamed his problem on lack of love from his parents as a child, but his parents described his childhood as normal, although they remembered that he became argumentative and arrogant during his teens. They had only recently learned of his lifestyle.

He was reluctant to discuss his sexual history but did say that as a teenager he masturbated by rubbing his body on his bed sheets, without using his arms. In his early adult life he had one long-term girlfriend, and he was married for a short time during his 20 s. He refused permission to contact his ex-wife.
He now lives in a flat adapted for a previous tenant who was disabled. He dresses by manoeuvring his body into clothes which are hung up to allow this. He uses his feet for most other activities. He eats ready-made meals from the floor and drinks through a straw. When he is shopping, a sales assistant carries his basket. He has not worked for several years but currently attends court with a solicitor who (unsuccessfully) defended his driving licence, and he intends to study law.

$\mathrm{He}$ is often irritable, and at times condescending or over-familiar. His speech is meticulous and circumstantial. His mood is objectively and subjectively euthymic. He has no abnormal beliefs about the function or appearance of his arms and is clear that he chooses not to use them. He has no other abnormal beliefs or experiences. His intelligence and cognitive state appear normal. Physical examination, neuropsychological testing, and full investigation have been normal.

There is no evidence of an organic disorder or of psychotic illness or major affective disorder. His symptoms are similar to the non-delusional overvalued ideas described by McKenna (1984). His presentation has some features in common with dysmorphophobia (Andreasen \& Bardach, 1977) but is atypical in that he accepts there is nothing wrong with the appearance of his arms.

Some features, such as repudiation of bodily parts and the history of an impoverished childhood, are similar to those described in non-psychotic genital self-mutilators (Greilsheimer \& Groves 1979). His conscious motivation makes hysteria unlikely, but malingering seems an inadequate explanation. The psychological factors that have led him to present in this way are similarly unclear. Currently, reinforcement is being provided by the concern of mental health services. An alternative view of this entrenched pattern of behaviour is that Mr X has found himself in a predicament from which he cannot escape (Taylor, 1979).

ANDReasen, N. C. \& BARDACH, J. (1977) Dysmorphophobia: symptom or disease? American Journal of Psychiatry. 134, 673-676.

Gremshemmer, H. \& Groves, J. C. (1979) Male genital selfmutilation. Archives of General Psychiatry, 36, 441-446.

McKennA, P. J. (1984) Disorders with overvalued ideas. British Journal of Psychiatry, 145, 579-585.

TAYLOR, D. C. (1979) The components of sickness: diseases, illnesses and predicaments. Lancet, 1008-1010.

Prestwich Hospital

DENISE RIORDAN

Manchester M25 7BL

LOUIS APPLEBY

Department of Psychiatry

Withington Hospital

Manchester M20 8LR 